\title{
Taxes, Expenditure and Development Nexus: A Panel VECM Analysis on Romanian NUTS2 Regions
}

\author{
By Marius Surugiu ${ }^{1}$, Camelia Surugiu ${ }^{2}$, Raluca Mazilescu ${ }^{3}$, Anca Cristea $^{4}$
}

\begin{abstract}
The investigation starts with the computation of the Socio-Economic Development Index (SEDI index) with data for Romania. Based on the index values, the long-run relationship between taxes and expenditure is assessed, for Romanian NUTS2 regions from 2000 to 2016. According to the results, there is a Granger causality relationship from budget revenue and expenditure to SEDI. The results emphasize the significant impact of taxes and expenditure on socio-economic development. The paper underlines the need for effective public strategies to be implemented by the authorities at the regional level, which may propel the socio-economic development. The results support the fiscal synchronization hypothesis.
\end{abstract}

Keywords: taxes, expenditure, socio-economic development, unit root test, cointegration, VECM, Granger causality, Romania, NUTS2 regions

\section{Introduction}

Taxes and expenditure may have significant effects on the economy, both positive and negative ones. In the literature, various studies focused on the relationships between tax revenue, expenditure, and development. The results of previous investigations from literature are mixed and pointed out the importance of the various influence factors such as the time analysis period, the countries analysed, the selected methodology etc.

For an accurate assessment of the effects of various measures adopted by governments to support the development process, the authors displayed a special interest in investigating the relationship between tax policy and other macroeconomic variables. Governments levy various taxes to raise revenue to the budget. With the changes that have occurred in the society, linked to the emergence of new ideas, new theories, new development models, to different socio-economic circumstances, the goal of taxes has undergone some changes. Thus, in addition to raising public revenue, the taxes levied may also influence some aspects such as consumption, output, etc. Moreover, according to the literature, a relationship between taxes levied and the level of development of a country exists, which may be influenced, because tax revenue may be used to boost the economic activity in various areas or countries. Various factors may influence the economic development of a country, including the design and implementation of an efficient tax policy.

Tax policy is an important factor influencing the stability and sustainability of economic

\footnotetext{
| ${ }^{1}$ Institute of National Economy, Romanian Academy, Bucharest, Romania

${ }^{2}$ Faculty of Administration and Business, University of Bucharest, Romania; National Institute for Research and Development in Tourism, Bucharest, Romania 
growth (Engen, E., Skinner, 1996), (Perotti, 2004), (Ocnean, 2006), (Afonso, A., Furceri, 2008), (Brasoveanu, L.O., Brasoveanu, 2008), (Mashkoor, M., Yahya, S., Ali, 2010), (Woo, 2011). Tax policy and economic policy are interrelated, and the tax burden depends on various policies in the areas of labour, industry, housing, natural resources (Jensen, C.V., Nielsen, 2003).

The tax system supports the effectiveness of government spending which, in return, contributes to the economic growth; also, value-added tax (VAT) system has a significant positive effect in sustaining government discipline of tax revenue management (Chan, S.G., Ramly, Z., \& Mohd Zaini Abd Karim, 2017). Taxes raise the government revenue, support the authority of states, and increase the accountability between the government and citizens (Weyzig, F., van Dijk, 2009).

Stability and sustainability of the economic growth are influenced by public expenditure (Devarajan, S., Swaroop, V., Zou, 1996), (Zhang, T., Zou, 1998), (Baldacci, E., Hillman, A.L., Kojo, 2004), (Angelopoulos, K., Economides, G., Kammas, 2007), (Alexiou, 2009). Government expenditure represents an important tool used in various situations. This variable may influence aggregate demand, inflation, employment, poverty, inequalities, economic stability, economic growth, and development. Policymakers may use this indicator in an attempt to improve income distribution, in the process of resource allocation, etc. That is why, in various countries, the role of government expenditure is highly significant.

In the literature, the link between fiscal policy and socio-economic development is investigated, using the Socio-Economic Development Index - SEDI (Mehrotra, A.N., Peltonen, 2005). Those authors compute the SEDI Index with the available data on health, infrastructure, environment, and education, using country-level data from the World Bank (World Development Indicators (WDI) 2003 Database), for the period 1980-1999.

The current research aims firstly to develop a SEDI Index for the case of Romanian NUTS2 regions, and secondly, to investigate the relationships between taxes, expenditure, and SEDI. SEDI may represent an alternative measure of NUTS2 regions development level. Also, the relationship between development, taxes and expenditure is an important topic, having in mind the important influences underlined by the literature, for example:

- changes in the economy may influence the tax system developments;

- the efficiency losses brought by taxes may be reduced to a minimum by using welldesigned tax systems;

- the use of well-designed tax systems may have an impact on raising the growth rate;

- public goods are developed using tax revenue, thus influencing the productivity level of the economy, and so on.

The present paper is structured as follows. The second section describes previous research findings regarding the relationship between taxes - economic growth - economic development, and also between expenditure and economic growth. The methodology is presented in the third section of the paper. In the fourth section, the data are analysed and the findings discussed. In the last section, the conclusions of the paper are underlined. 


\section{Literature Review}

\subsection{Taxes - Growth Nexus}

In the literature, various studies focused on the relationship between economic growth, taxation, and economic development. The empirical researches underlined the effect of taxation on economic growth (Macek, 2014). Some authors even identified the signs of these relationships, positive or negative, or the directional causality. Tax revenue and economic growth have a positive relationship (Olatunji, T.M. \& Sunday, 2012), (Lien N.P., 2017). The same situation is between the total tax revenue growth rate and GDP growth rate (Surugiu, M.R.; Surugiu, C. \& Nica, 2012). The tax mix is influenced by economic growth (Tosun, M.S., Abizadeh, 2005). Progressive tax policy may support economic stability. This is related to its correlation with countercyclical fiscal policy and income equality (Weller, C., Rao, 2010).

In the literature, the economic growth and the tax structure have a direct link (Engen, E., Skinner, 1996). The tax system and the tax policy have effects on long-run economic growth. A high level of direct taxation favours real growth. The ratio between direct taxes and GDP significantly Granger causes real GDP growth (Mashkoor, M., Yahya, S., Ali, 2010).

GDP growth and top tax rates have a nonmonotonic relationship (Milasi, S., Waldmann, 2018). The personal income top marginal tax rates encourage cumulative growth when the revenue was used to finance the expenditure in $\mathrm{R} \& \mathrm{D}$, education, limit the budget deficit, decrease social insurance contribution, reduce taxes in goods and services. Moreover, a strong relationship exists between development and tax structure (Easterly, W., Rebelo, 1993). The public finance has a positive role in the development process (Smith, P., Wahba, 1994), and the tax breaks are necessary to support business investment and economic development (Matkin, 2010). Tax revenue has a positive long-run effect on growth (Hlongwane T.M., Mongale I.P., 2018).

Another group of empirical investigations indicated that a high level of taxation can lead to a slowdown in economic growth (Mandl, U., Dierx, A., Ilzkovitz, 2008). The tax cuts may fail to positively influence economic growth because they do not necessarily reward productivity or efficiency (Riedl, 2008). There are also some negative effects of taxes on economic growth (Brasoveanu, L.O., Brasoveanu, 2008).

A negative relationship between tax burden, regulations and the service sector development exist. This link may be influenced by the industry, the economic cycle and the economic development level (Fang, H., Yu, L., Hong, Y, Zhang, 2019). The consumption tax rate growth generates a raise or a decrease in the GDP growth rate, depending on the monetary policy (Kaneko, A., Matsuzaki, 2009).

Labour income tax rates and economic growth have a negative link (Angelopoulos, K., Economides, G., Kammas, 2007). A high level of taxation negatively influences economic growth, because it does not motivate people to work (Mitchell, 2006). Social contributions and indirect taxes have an undesirable effect on economic growth (Afonso, A., Furceri, 2008).

Some authors are more reserved concerning the nature of the relationship tax - growth development. Economic growth may be influenced by tax policy. The output growth may 
be slightly influenced by tax policy beneficial changes. (Engen, E., Skinner, 1996). Also, there may be no significant effect of the income tax on economic growth (CanavireBacarreza, G.; Martinez-Vazquez, J. \& Vulovic, 2013). The corporation tax has a reduced negative effect, and consumption taxes have an important positive impact on growth. There are weak effects of tax cuts on GDP (Perotti, 2004). Once the GDP grows, the taxation performance will decline, after achieving the optimal level (Loganathan, N., Ismail, S., Streimikiene, D., Hassan, A.A.G, Zavadskas, E.K., Mardani, 2017). There is unidirectional causality from GDP to taxation. Innovation-based growth model indicated that capital taxation and economic growth have a positive link in high-income countries, and less positive or negative in countries with a low level of income (ten Kate, Fabian, Milionis, 2019).

\subsection{Expenditure - growth nexus}

Besides taxation, another important variable, namely public spending, exerts a significant impact on the economy, underlying the necessity to identify the changes in public policy (Blanchard, O., Perotti, 1999). Public spending - growth - development link is complex, and various authors identified some connection models. Fiscal policy may influence economic development, in both positive and negative directions.

Fiscal consolidation was considered relevant in promoting socio-economic development, lending and reducing the level of public debt; also it is considered beneficial for mediumterm socio-economic development (Mehrotra, A.N., Peltonen, 2005). In the investigation of the economic development - fiscal policy relationship, variables such as GDP per capita, tax burden, public expenditure to GDP ratio, and budget deficit to GDP ratio may be used (Ocnean, 2006).

Public spending and economic growth have a positive link (Dandan, 2011), (Herath, 2012), (Surugiu, M.R.; Surugiu, C. \& Nica, 2012). Productive expenditure, capital expenditure, and growth have a positive link (Olatunji, T.M. \& Sunday, 2012). Public spending has a positive effect on growth, with a long-run equilibrium (Gangal, V.L.N. \& Gupta, 2013). Expenditure and economic growth have a long-run relationship (Lien N.P., 2017).

The reallocation of public spending implies an increase in education expenditure, with an important positive effect on growth, associated with a reduction in spending on social protection (Acosta-Ormaechea, S. \& Morozumi, 2013). Also, economic growth may be positively influenced by education expenditure (Chude, N.P. \& Chude, 2013).

Other authors consider that the use of discretionary fiscal policies does not support the economic growth; countries with unequal distribution of the initial income tend to show higher volatility of fiscal spending (Woo, 2011). Also, some studies show that the economic growth is not influenced by the level of expenditure (Bağdigen, M., Çetintaş, 2004) and that the rise in non-productive public spending may hinder economic growth (Baldacci, E., Hillman, A.L., Kojo, 2004). Some interesting results showed that the fiscal policy impact on GDP is low, and the effects of public spending shocks on GDP are weak (Perotti, 2004).

\section{Data and Methodology}

\subsection{Data collection}


The Socio-Economic Development Index - SEDI is used in the analysis from this paper, based on the methodology from literature (Mehrotra, A.N., Peltonen, 2005). The current analysis is also focused on conducting the unit root (UR) test, the cointegration investigation, the application of the vector error correction model (VECM), and the study of the Granger causality.

The analysis is performed at the Romanian NUTS2 level, for the eight development regions, namely: North-West (NW), Centre (C), North-East (NE), South-East (SE), South-Muntenia (S), Bucharest-Ilfov (B), South-West Oltenia (SW), and West (W). The development regions were created in 1998 through the association of the county councils from Romania, to coordinate the regional development necessary for the country to accede to the European Union. These regions do not have an administrative status, legislative council or executive body, and represent only the free agreement between the county and local councils. The most developed region, considering the GDP per capita indicator, is Bucharest-Ilfov, which includes the capital of the country (Bucharest), while the least developed is the North-East Region.

SEDI Index is computed for Romanian NUTS2 level, using the available data, taking into consideration the following variables: the passengers transported in local public transport (thousands of persons); the total length of the drinking water distribution network (kilometres); the total length of the gas distribution pipes (kilometres); the regional gross domestic product (millions lei, current prices); the school population (number of persons); the infant mortality rate (deceased under 1 year per 1000 live births).

The panel data analysis with both dependent and independent variables covers the period 2000-2016. In Romania, this period is characterised by various measures adopted in the area of indirect taxation. In the year 2000, new categories of products, subject to excise duties, were introduced in the tax legislation (gasoline, unleaded gasoline, diesel, heating fuel, other petroleum products resulting from oil processing, oil for motor vehicles, etc.). The level of excise duties has gradually changed to reach the mandatory level applied in the EU. In the area of VAT, the standard rate has undergone successive changes, from $19 \%$ in 2004 to $24 \%$ in $2006,19 \%$ in $2008,24 \%$ in $2010,20 \%$ in 2016 , and $19 \%$ since January 1, 2017. The reduced rate was $9 \%$ in 2004, applied for the access to museums, castles, zoos, and botanical gardens, etc.; the delivery of newspapers, schoolbooks, magazines, and medicines, etc. In 2008, the reduced rate was $9 \%$ for pharmaceuticals, books, hotel accommodation, etc. In 2009 , the reduced rate was $5 \%$ for social housing and several categories of private housing. The 9\% reduced rate was in 2013 for bakery products, bread, flour, etc. In 2016, the reduced rate of 5\% was for school textbooks, books, newspapers, magazines, access to castles, museums, cinemas, etc.

The tax revenue registered constant increases, interrupted by reductions and significant variations, especially in the period following the financial crisis of 2007-2008. Also, the level of expenditure registered stagnations or reductions, by regions, after this event. 


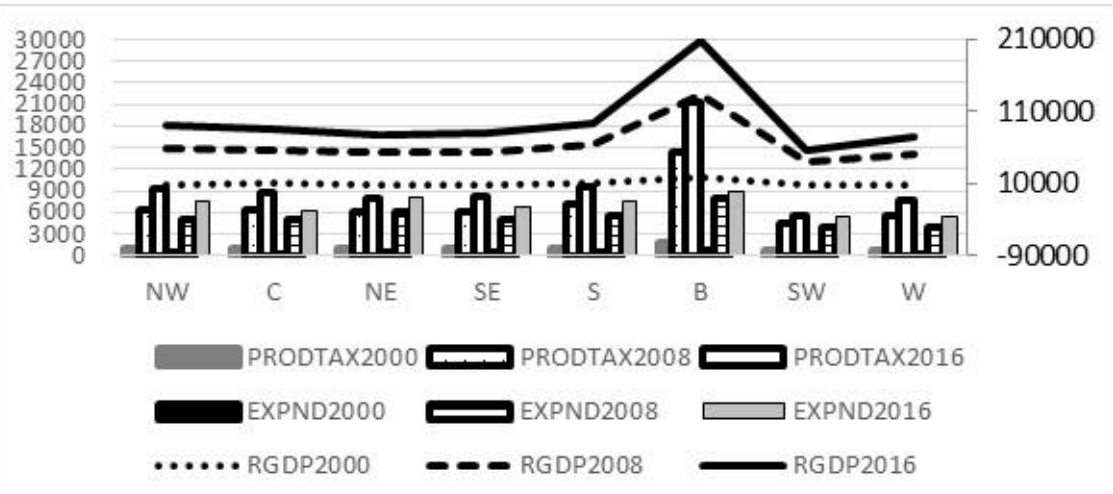

Note: NW-North-West Region, C-Centre Region, NE-North-East Region, SE-SouthEast Region, S-South-Muntenia Region, B-Bucharest-Ilfov Region, SW-South-West Oltenia Region, W-West Region

Figure 1. Taxes on products, including VAT (PRODTAX), expenditure of the local budgets (EXPND), and regional GDP (RGDP), millions of lei, current prices, 2000, 2008, 2016

Source: Romanian National Institute of Statistics (Tempo Online Database); RGDP on $2^{\text {nd }} 0 y$ axis

The regional analysis identifies a correlation between the level of development (GDP), taxes on products and expenditure of the local budgets. The region with the highest contribution to the tax revenue is Bucharest - Ilfov, by far the most developed region in the country, which concentrates also the highest level of expenditure of the local budget. The second region, considering the level of development in terms of GDP, is South Muntenia, and it collects an important amount of revenue from taxes on products, including VAT. Also, the expenditure level is the fourth in terms of volume. It is worth mentioning that even if the North-West Region is the third most developed region in the country in terms of GDP and it is placed on the third position in terms of revenue and expenditure. In 2016, the Centre Region is placed fourth in terms of GDP and taxes on products, but sixth in terms of expenditure. The North-East Region is placed sixth as regards GDP and taxes on products but is the second region regarding the expenditure of the local budget (see Fig. 1).

The independent variables used in the econometric analysis are the taxes on products, including VAT, millions of lei, current prices - PRODTAX, and the expenditure of the local budgets - total, millions of lei, current prices - EXPND.

The data source is the Romanian National Institute of Statistics (Tempo Online Database). The taxation - expenditure - SEDI long-run relationship at NUTS2 level is analysed based on these specific variables.

\section{Methodology Description}

The SEDI index was computed for several years, by NUTS2 development regions of Romania. The SEDI index is an indicator that reflects the qualitative and quantitative aspects of the socio-economic development and it considers the max-min gap. A feature of the indicator is that it offers an image of the regional socio-economic development level and the sustainability of growth potential. The higher the value obtained, the more 
developed the region is. SEDI index value is given by:

$S E D I_{i}=\frac{\sum_{j=1}^{J} \text { index }_{i j}}{J}$

In equation (1), $\mathrm{J}$ is the number of indicators; $\mathrm{i}$ is the number of regions.

index $_{i j}=\frac{\operatorname{var}_{i j}-\min _{j}}{\max _{j}-\min _{j}}$,

In equation (2), $\operatorname{var}_{i j}$ is the value for $j$ indicator from $i$ region, $\min _{j}$ is the minimum value for $j$ indicator, and $\max _{j}$ is the maximum value for $j$ indicator.

The SEDI index values are between 0 and 1. Thus, SEDI index for each $i$ region is obtained using the arithmetic mean of $J=$ number of indicators for $i$ region.

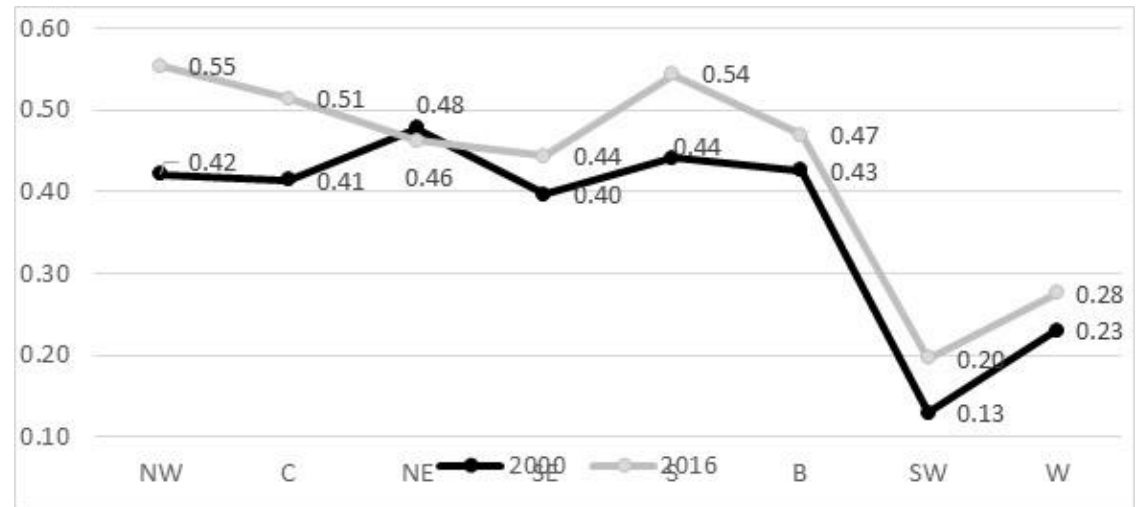

Figure 2. Sedi computed for Romanian nuts2 regions, 2000 vs. 2016

Source: authors' computations.

The SEDI index values computed for 2000 and 2016 show the classification of the NUTS2 regions, which remains the same, except the situation of the North-East Region. Between 2000 and 2016, SEDI computed values registered a different evolution from region to region. There are two regions where the values obtained are the lowest, namely: West Region and South West Region (see Fig. 2). Also, the results are different, if we compare the development level (GDP per capita) with SEDI values at the regional level, showing that SEDI is an important alternative measure for the development level.

The following section is focused on the econometric analysis, and the results are obtained using the Panel Unit Root (PUR) tests, Johansen Fisher Panel Cointegration (JFPC) test, Panel VECM, Wald test, and Pairwise Granger Causality (PGC) tests.

Regarding the PUR tests, the following are computed: Levin, Lin, and Chu (LLC) test (Levin, A., Lin, C.F., Chu, 2002) and Fisher-type tests using ADF and PP tests (Maddala, G.S., Wu, 1999), (Choi, 2001). The common unit root process exists. The cross-sections have identical autoregressive coefficients. The unit root null hypothesis is used. Individual unit root processes are allowed by Fisher-ADF and PP tests. The cross-sections may have autoregressive coefficients that may vary (Levin, Lin, and Chu (LLC) test).

According to the literature, for the PUR tests, the Fisher's results (Fisher, 1932) are used to derive tests combining the individual UR test $p$-values (Maddala, G.S., Wu, 1999), (Choi, 2001). 
Regarding the JFPC test, a Fisher-type of panel cointegration test with the Johansen methodology (Maddala, G.S., Wu, 1999) is used in the analysis. In the literature, the individual independent tests results are employed into a combined test (Fisher, 1932), and the results are used to propose the panel data cointegration testing, combining individual cross-sections tests to get the panel test (Maddala, G.S., Wu, 1999). In the paper, the $p$ values for Johansen's cointegration trace test and maximum eigenvalue test are reported (MacKinnon, J.G., Haug, A.A., Michelis, 1999).

The series considered non-stationary and cointegrated are used in VECM (restricted VAR). The model contains the cointegration relations in the specification, which permit the adjustment dynamics on short-run and restrict the behaviour of the endogenous variable on long-run (convergence to cointegrating relationships).

The error correction term is the cointegration term and is nonzero for a system that deviated from the long-run equilibrium. The short-run adjustments correct the deviation from the long-run equilibrium. The adjusting variables related to restoring the equilibrium and the endogenous variables adjustment speed towards the equilibrium can be measured. The Wald test underlines that the restrictions are satisfied by unrestricted estimates (considering the null hypothesis). The statistics $p$-values are important in showing that the results reject, or not, the null hypothesis.

An endogenous variable is treated as exogenous if this is confirmed by the PGC tests. The results underline the lagged endogenous variables' joint significance.

\section{Data Analysis and Findings}

The analysis is focused on the relationship between SEDI and PRODTAX / EXPND variables. The steps of the analysis are the test for panel unit root, the cointegration test, the development of the panel VECM model, and the Wald test.

\subsection{Panel Unit Root Tests}

Before conducting cointegration tests, all variables should have the same properties, meaning they should be integrated of the same order.

Table 1. PUR test statistics

\begin{tabular}{|l|c|c|c|}
\hline Variables & Levin, Lin \& Chu & ADF & PP \\
\hline SEDI & -0.18 & 8.27 & 8.79 \\
\hline PRODTAX & 5.68 & 0.30 & 0.32 \\
\hline EXPND & 5.23 & 1.37 & 0.30 \\
\hline First difference & $-10.44^{* * *}$ & $111.02^{* * *}$ & $109.73^{* * *}$ \\
\hline D $($ SEDI $)$ & $-5.77^{* * *}$ & $52.68^{* * *}$ & $70.38^{* * *}$ \\
\hline D(PRODTAX) & $-4.74^{* * *}$ & $41.85^{* * *}$ & $44.15^{* * *}$ \\
\hline D(EXPND) & \multicolumn{4}{|l|}{} \\
\hline Note: ${ }^{* * *} p$-value $\leq 0.001$ &
\end{tabular}

Source: authors' computations

The tests indicate that the series are stationary in first difference and integrated of order one, I(1). In the following, the cointegrations analysis is developed. 


\subsection{Cointegration Tests}

The cointegration criteria are analysed with Johansen cointegration test when testing variables' relationship hypotheses (Johansen, 1988). In the case of a stationary linear combination (two or more non-stationary series may be stationary), the non-stationary series are considered cointegrated (Engle, R.F., Granger, 1987).

To detect long-run relationships, the JFPC test is employed. At least two cointegrating equations may exist between the variables ( $p$-value $\leq 0.001)$. For trace test, there is one cointegration equation ( $p$-value $\leq 0.01)$. The conclusion underlines the long-run equilibrium. The analysis is developed by using the Panel VECM, to check the variables' interaction.

Table 2. JFPC Test

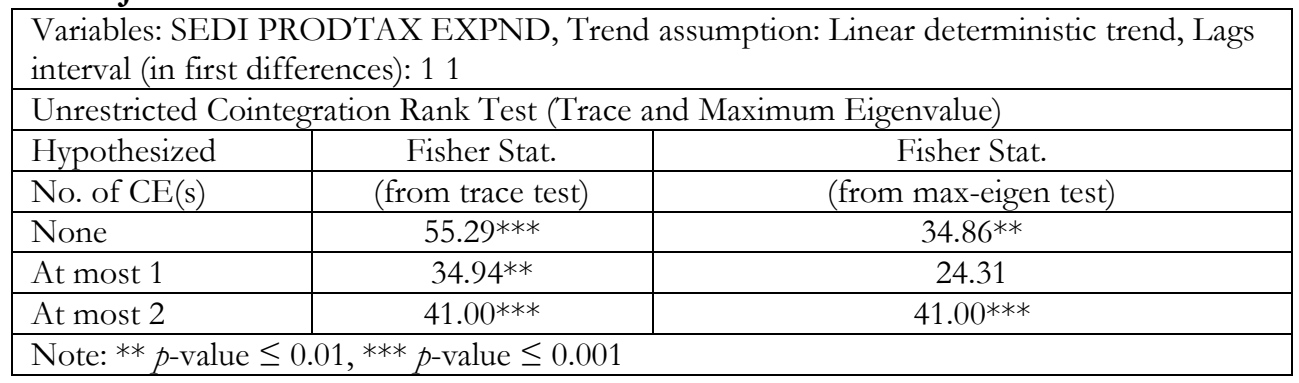

Source: authors' computations

\subsection{Panel VECM Model}

The unit root is confirmed by the UR test and cointegration tests. Cointegration is a feature of the non-stationary series. In the following, a VECM is developed, to analyse the nature of the non-stationarity of the variables. The VECM underlines the speed of return to equilibrium after a shock, and the equation is written as follows ( $\mathrm{R}$-squared is $0.61)$ :

$D(S E D I)=C(1) *($ SEDI $(-1)+4.772 e-06 * P R O D T A X(-1)-9.376 e-05 * E X P N D(-1)+0.072)+$ $C(2) * D(S E D I(-1))+C(3) * D(S E D I(-2))+C(4) * D(P R O D T A X(-1))+C(5) * D(P R O D T A X(-2))+$ $C(6) * D(\operatorname{EXPND}(-1))+C(7) * D(\operatorname{EXPND}(-2))+C(8)$,

and

$D(S E D I)=-0.314 *($ SEDI $(-1)+4.772 e-06 *$ PRODTAX $(-1)-9.376 e-05 * E X P N D(-1)+0.072)+$ $0.008 * D(S E D I(-1))+0.068 * D(S E D I(-2))-3.30 e-05 * D(P R O D T A X(-1))-4.06 e-06 * D(P R O D T A X(-$ 2)) $-9.65 e-05 * D(\operatorname{EXPND}(-1))+6.06 e-05 * D(\operatorname{EXPND}(-2))+0.045$,

Based on the results, the variables are characterised by causality on long-run (from independent to dependent ones). To get to the long-run equilibrium, the speed of adjustment is $3.14 \%$ annually (C(1) value) for the whole system.

\subsection{Wald Test}

As cointegrating relationships exist, Wald test and PGC tests are used for causality check. The Wald test and PGC tests show a short-run causality running from taxes and expenditure to SEDI (dependent variable). 
Table 3. WALD Test, DF: 4

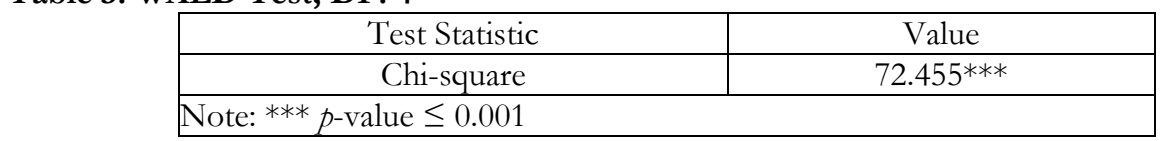

Source: authors' computations

Table 4. PGC Tests, Lags: 2

\begin{tabular}{|l|c|c|c|}
\hline Dependent variable & SEDI & PRODTAX & EXPND \\
\hline SEDI & - & $28.186^{* * *}$ & $22.539 * * *$ \\
\hline PRODTAX & 1.272 & - & $5.479 * *$ \\
\hline EXPND & 0.515 & $4.335^{*}$ & - \\
\hline Note: $* p$-value $\leq 0.05, * * p$-value $\leq 0.01, * * *$ & $p$-value $\leq 0.001$ & \\
\hline
\end{tabular}

Source: authors' computations

An interesting result shows the feature of the government expenditure - tax revenue (indirect taxes) link of bi-directional causality, which supports the fiscal synchronization hypothesis, justified by previous studies (Musgrave, 1966), (Meltzer, A.H., Richard, 1981). The fiscal synchronization hypothesis underlines that spending and revenue decisions of the government are made simultaneously (or jointly), meaning that spending and revenue are interdependent, characterised by a bi-directional causality relationship. This result highlights the important role of indirect tax revenue for the budget. Thus, these findings underline the importance of these taxes for the future development of public programs and strategies.

\section{Conclusions}

The results of the study emphasize that tax revenue and expenditure have an important effect on socio-economic development. Policymakers should search for the optimal point in raising revenue, so necessary for public budget projects (expenditure side). The development of the tax system should take into account the structural changes within the society and economy.

In the paper, the analysis focused on the case of Romania, using a methodology that considered the main aspects regarding the impact of government revenue and expenditure on the economy, with the computation of the SEDI index in the analysis of the tax/expenditure - socio-economic development relationship.

Different policies may exert various influences within the economy, through taxes and expenditure: measures adopted to protect low-income taxpayers, to limit the consumption of products with undesirable impact on the population and the environment, to encourage production, to stimulate investments, saving, exports, etc.

Policymakers should identify efficient measures of directing the revenue to public projects needed in low developed regions, to support regional economic convergence. Demographic changes may exert significant pressures on the tax base, in low developed regions, which are often confronted with the phenomenon of (e)migration. Under these conditions, policymakers should try to develop efficient measures to direct revenue to these regions, to provide the indispensable resources for the development and for increasing the standard of living. 
Taxes are tools, which may significantly shape the existing relationships between the state and the citizens. Tax revenue allows the policymakers to finance projects benefiting all taxpayers, but also the social security system, the national defence, etc. Tax reforms may be considered as key elements for an effective policy-making process in this area, with an important role in any country.

Analysing the development of the Romanian NUTS regions, the convergence was not homogeneous, and there was not the same pace of recovery of the disparities. While for the Bucharest-Ilfov Region, the GDP registered a significant increase, at the level of other regions (eg North-East and South-West Oltenia regions), the values of the indicator are smaller.

Despite the growth registered, the level of tax revenue to GDP is in a slight decline, with values below the EU average. Thus, the focus on public debt and budget deficits is emphasized, which must be carefully considered in future research.

In general, when it comes to taxes, and especially to raising tax rates or other measures of this kind, the population may express some resistance. But such an attitude towards taxation is certainly the greatest challenge for the policymakers, in their attempt to identify the necessary elements, the appropriate "ingredients" to develop an efficient tax system. Taxes levied on a certain economic activity should support its development, as well as the development of other sectors of the economy that depend on such activity.

Future research should consider some improvements related to the extension of the data period and the content of the SEDI index. Also, future analysis should regard a proper investigation of the fiscal synchronization hypothesis, for the case of Romania.

\section{References}

Acosta-Ormaechea, S. \& Morozumi, A. (2013). Can a Government Enhance Long-Run Growth by Changing the Composition of Public Expenditure? (WP/13/162).

Afonso, A., Furceri, D. (2008). Government Size, Composition, Volatility and Economic Growth (No 849 / January 2008).

Alexiou, C. (2009). Government Spending and Economic Growth: Econometric Evidence from the South Eastern Europe (SEE). Journal of Economic and Social Research, 11(1), 1-16.

Angelopoulos, K., Economides, G., Kammas, P. (2007). Tax-spending policies and economic growth: Theoretical predictions and evidence from the OECD. European Journal of Political Economy, 23, 885902.

Bağdigen, M., Çetintaş, H. (2004). Causality between Public Expenditure and Economic Growth: The Turkish Case. Journal of Economic and Social Research, 6(1), 53-72.

Baldacci, E., Hillman, A.L., Kojo, N. C. (2004). Growth, governance, and fiscal policy transmission channels in low-income countries. European Journal of Political Economy, 20, 517-549.

Blanchard, O., Perotti, R. (1999). An empirical characterization of the dynamic effects of changes in government spending and taxes on output (NBER WP7269).

Brasoveanu, L.O., Brasoveanu, I. (2008). The Correlation between Fiscal Policy and Economic Growth. Theoretical and Applied Economics, 19-26.

Canavire-Bacarreza, G.; Martinez-Vazquez, J. \& Vulovic, V. (2013). Taxation and Economic Growth in Latin America (IDB-WP-431).

Chan, S.G., Ramly, Z., \& Mohd Zaini Abd Karim, M. Z. A. (2017). Government Spending Efficiency on Economic Growth: Roles of Value-added Tax. Global Economic Review, 46(2), 162-188.

Choi, I. (2001). Unit Root Tests for Panel Data. Journal of International Money and Finance, 20, 249-272.

Chude, N.P. \& Chude, D. I. (2013). Impact of Government Expenditure on Economic Growth in Nigeria. International Journal of Business and Management Review, 1(4), 64-71. 
Dandan, M. M. (2011). Government Expenditures and Economic Growth in Jordan. IPEDR, 4, 1320-1338. Devarajan, S., Swaroop, V., Zou, H. (1996). The composition of public expenditure and economic growth. Journal of Monetary Economics, 37, 313-344.

Easterly, W., Rebelo, S. (1993). Fiscal policy and economic growth: An empirical investigation. Journal of Monetary Economics, 32, 417-458.

Engen, E., Skinner, J. (1996). Taxation and Economic Growth. National Tax Journal, 49(4).

Engle, R.F., Granger, C. W. J. (1987). Co-integration and Error Correction: Representation, Estimation, and Testing. Econometrica, 55, 251-276.

Fang, H., Yu, L., Hong, Y, Zhang, J. (2019). Tax Burden, Regulations and the Development of the Service Sector. Emerging Markets Finance and Trade, 55(3), 477-495.

Fisher, R. A. (1932). Statistical Methods for Research Workers (4th ed.). Oliver \& Boyd.

Gangal, V.L.N. \& Gupta, M. H. (2013). Public Expenditure and Economic Growth, A Case Study of India. Global Journal of Management and Business Studies, 3(2), 191-196.

Herath, S. (2012). Size of government and economic growth: a nonlinear analysis. Economic Annals, LVII(194). Hlongwane T.M., Mongale I.P., T. L. (2018). Analysis of the Impact of Fiscal Policy on Economic Growth in South Africa: VECM Approach. Journal of Economics and Behavioral Studies, 10(2), 231-238.

Jensen, C.V., Nielsen, S. (2003). Tax policy on the outskirts of the EU: Greenland. Baltic Journal of Economics, 4(1), 46-63.

Johansen, S. (1988). Statistical Analysis of cointegration vectors. Journal of Economic Dynamics and Control, 12, 231-254.

Kaneko, A., Matsuzaki, D. (2009). Consumption tax and economic growth in an overlapping generations model with money holdings. Journal of Economics, 98(2), 155-175.

Levin, A., Lin, C.F., Chu, C. (2002). Unit Root Tests in Panel Data: Asymptotic and Finite-Sample Properties. Journal of Econometrics, 108, 1-24.

Lien N.P., T. S. D. (2017). Tax revenue, expenditure, and economic growth: An analysis of long-run relationships. Journal of Economic Development, 24(3), 4-26.

Loganathan, N., Ismail, S., Streimikiene, D., Hassan, A.A.G, Zavadskas, E.K., Mardani, A. (2017). Tax Reform, Inflation, Financial Development and Economic Growth in Malaysia. Romanian Journal of Economic Forecasting, 20(4), 152-165.

Macek, R. (2014). The Impact of Taxation on Economic Growth: Case Study of OECD Countries. Review Of Economic Perspectives, 14(4), 309-328.

MacKinnon, J.G., Haug, A.A., Michelis, L. (1999). Numerical Distribution Functions of Likelihood Ratio Tests for Cointegration. Journal of Applied Econometrics, 14, 563-577.

Maddala, G.S., Wu, S. (1999). A Comparative Study of Unit Root Tests with Panel Data and a New Simple Test. Oxford Bulletin of Economics and Statistics, 61(631-652).

Mandl, U., Dierx, A., Ilzkovitz, F. (2008). The Effectiveness and Efficiency of Public Spending, European Economy (Economic Papers 301).

Mashkoor, M., Yahya, S., Ali, S. A. (2010). Tax Revenue and Economic Growth: An Empirical Analysis for Pakistan. World Applied Sciences Journal, 10(11), 1283-1289.

Matkin, D. (2010). Designing Accountable and Effective Economic Development Tax Incentives. Public Performance \& Management Review, 34(2), 166-188.

Mehrotra, A.N., Peltonen, T. A. (2005). Socio-Economic Development and Fiscal Policy: Lessons from the Cohesion Countries for the New Member States (Working Paper Series, No. 467).

Meltzer, A.H., Richard, S. F. (1981). A rational theory of the size of government. Journal of Political Economy, 89, 914-927.

Milasi, S., Waldmann, R. (2018). Top marginal taxation and economic growth. Applied Economics, 50(18), 21562170.

Mitchell, D. (2006). Fiscal Policy Lessons from Europe. http://www.heritage.org/Research/Reports/2006/10/Fiscal-Policy-Lessons-from-Europe

Musgrave, R. (1966). Principles of budget determination. In H. C. \& W. Henderson (Ed.), Public finance: Selected readings. Random House.

Ocnean, A. S. (2006). Studiu empiric privind conexiunea politică fiscală - dezvoltare economică. Theoretical and Applied Economics, 9(504).

Olatunji, T.M. \& Sunday, A. A. (2012). Econometrics Analysis of the Impact of Fiscal Stance on Economic Growth in Nigeria (1970-2010). Prosiding Perkem, VII(JILID 1), 488 - 508. 
Perotti, R. (2004). Estimating the effects of fiscal policy in OECD Countries (Working Paper n. 276).

Riedl, B. (2008). Why Government Spending Does Not Stimulate Economic Growth. http://www.heritage.org/Research/Reports/2008/11/Why-Government-Spending-Does-NotStimulate-Economic-Growth

Smith, P., Wahba, J. (1994). The Role of Public Finance in Economic Development: An Empirical Investigation (Working Paper 9508).

Surugiu, M.R.; Surugiu, C. \& Nica, M. (2012). Fiscal Policy and Economic Growth: Explanation with Empirical Analysis. Actual Problems of Economics, 8, 134.

ten Kate, Fabian, Milionis, P. (2019). Is capital taxation always harmful for economic growth? International Tax and Public Finance, 26(4), 758-805.

Tosun, M.S., Abizadeh, S. (2005). Economic growth and tax components: an analysis of tax changes in OECD. Applied Economics, 37(19), 2251-2263.

Weller, C., Rao, M. (2010). Progressive Tax Policy and Economic Stability. Journal of Economic Issues, 44(3), 629_ 659.

Weyzig, F., van Dijk, M. (2009). Incoherence between Tax and Development Policies: the case of the Netherlands. Third World Quarterly, 30(7), 1259-1277.

Woo, J. (2011). Growth, income distribution, and fiscal policy volatility. Journal of Development Economics, 96(2), 289-313.

Zhang, T., Zou, H. (1998). Fiscal decentralization, public spending, and economic growth in China. Journal of Public Economics, 67, 221-240. 